\title{
Investigation of porcine candidate genes for improving marbling score and meat quality traits in commercial swine breeds in Thailand
}

\author{
W. Kenchaiwong ${ }^{1,3}$, S. Kananit ${ }^{2,3}$, K. Tuangsithtanon ${ }^{4}$, M. Duangjinda ${ }^{2,3}$ \\ and W. Boonkum ${ }^{2,3}$ \\ ${ }^{1}$ Faculty of Veterinary Science, Mahasarakham University, Mahasarakham, \\ Thailand \\ ${ }^{2}$ Department of Animal Science, Faculty of Agriculture, Khon Kaen \\ University, Khon Kaen, Thailand \\ ${ }^{3}$ Network Center for Animal Breeding and OMICS Research, Khon Kaen \\ University, Khon Kaen, Thailand \\ ${ }^{4}$ Betagro Hybrid International Co., Ltd., Bangkok, Thailand \\ Corresponding author: W. Boonkum \\ E-mail:wboonkum@gmail.com
}

Genet. Mol. Res. 19 (2): gmr18615

Received April 16, 2020

Accepted May 23, 2020

Published June 30, 2020

DOI http://dx.doi.org/10.4238/gmr18615

\begin{abstract}
The objective of this research was to identify candidate gene markers based on their function related to marbling score and meat quality traits in pigs. A total of 313 commercial pigs with five different Duroc (DR) breed fractions: $1=100 \% \mathrm{DR}(\mathrm{n}=$ 227), $2=50 \% \mathrm{DR} \times 50 \%$ Large white $(\mathrm{LW})(\mathrm{n}=7), 3=50 \% \mathrm{DR} \times$ $50 \%$ Landrace $(\mathrm{LR})(\mathrm{n}=41), 4=75 \% \mathrm{DR} \times 25 \% \mathrm{LW}(\mathrm{n}=18)$, and $5=$ $50 \% \mathrm{DR} \times 25 \% \mathrm{LW} \times 25 \% \mathrm{LR}(\mathrm{n}=20)$ were measured for marbling score (score 3; MB3 and score 6; MB6), Color ( $\left.\mathrm{L}^{*}\right)$, \% cooking loss and shear force meat characters. The pigs were slaughtered at around 190 days of age, at an average weight of $122 \mathrm{~kg}$. Five candidate genes (LIPE, LEPR, ADRB3, CAPN1, and CAST) were genotyped by using -RFLP. The genetic parameters were estimated with Bayesian analysis via Gibbs sampling and analyzed by estimated breeding value by BLUP. The breed group had an effect on traits, especially marbling traits, percent cooking loss, and shear force. In Duroc purebreds, the marbling scores were significantly higher than in Duroc crossbreds. Al parameters were significantly higher in 50\%DR
\end{abstract}


x 50\% Large white (LW) compared with the others. Association analysis showed that the AG genotype of the ADRB3 gene had a higher marbling score than the GG genotype (2.22 vs 1.99 for MB3, 2.92 vs 2.49 for MB6; P < 0.05). The lowest estimated breeding values (EBVs) for color $\left(\mathrm{L}^{*}\right)(3.88)$ and \% cooking loss (2.64) were obtained in the CC genotype of the CAPNI gene. The GG genotype showed lower shear force and EBVs compared to the AG genotype of $C A S T$ gene $(4.08$ vs 4.85 for shear force $(\mathrm{P}<0.05)$ and -0.03 vs 0.05 for EBV's, $\mathrm{P}<0.01)$. The AG genotype of $A D R B 3$ could be used in marker assisted selection to improve marbling scores. Also, the GG genotype of CAST is the most appropriate for selection for pork tenderness.

Key words: Pigs; Gene association; Meat quality; Marbling score

\section{INTRODUCTION}

Meat quality is one of the key factors for consumers in purchasing decisions. The characteristics, i.e. color, juiciness, flavor, and tenderness, can affect consumer acceptance and are important in the competitive market of pig production (Fortin et al., 2005; Reardon et al., 2010). In addition, intramuscular fat and fatty acid composition has been shown to influence human health (Zhang et al., 2009; Xue et al., 2015). The candidate gene approach is used for difficult traits such as carcass and meat quality, sex and/or traits which show low heritability. The function of genes is frequently considered for candidate markers. The molecular markers can be applied with marker assisted selection (MAS) and/or for preselection in a breeding program. The polygene on the chromosomal regions known as quantitative trait loci (QTL) play a role in controlling meat quality traits (Cho et al., 2015), backfat thickness and intermuscular fat content (de Koning et al., 1999) in pigs. Several QTL markers for meat quality were detected in various populations. Linkage disequilibrium (LD) markers that can be transmitted within the population are frequently detected in the Duroc population (Gerbens et al., 1999; Cho et al., 2015). Currently, QTLs suitable for mapping, which can identify the major genes related to meat quality in term of fatness, are already known. Beta-3-adrenergic receptor gene $(A D R B 3)$ is responsible for encoding a major lipolytic and thermogenic mediator, which has an effect on adipose tissue. NowackaWoszuk et al. (2008) reported that the ADRB3 gene is close to a quantitative trait locus (QTL) region for fatness traits on chromosome 15. The hormone-sensitive lipase gene (LIPE) on chromosome 6 is expressed in adipose tissue and plays a role in hydrolyzing triglycerides for free fatty acid mobilization (Mellink et al., 1993; Miyoshi et al., 2008; Zechner et al., 2009). Polymorphisms of the ADRB3 and LIPE genes could be associated with the exhibition of intramuscular fat (IMF) in pigs, as reported by Xue et al. (2015). With regard to tenderness, several studies found that the calpain genes, i.e. calpain 1 and calpain 3, play important roles in tenderization processes (Huff-Lonergan and Lonergan, 2005; Gandolfi et al., 2011). Calpain 1 (CAPNI) encodes the large subunit ( $\mu$-calpain) of an enzyme which plays a role in proteolysis processes in pork (Huff-Lonergan and Lonergan, 2005; Kemp et al., 2010). High calpain activity leads to enhanced tenderness because it affects the cleavage of specific myofibrillar proteins (Gandolfi et al., 2011). Some studies 
have reported that calpain 3 could not be detected in pig meat (Parr et al., 1999), whereas others have stated that the porcine calpastatin $(C A S T)$ is an antagonist of calpain, which means that high activity leads to decreased proteolysis and increased meat toughness (Kent et al., 2004; Kemp et al., 2010). Furthermore, the leptin receptor gene (LEPR) is associated with tenderness in pork, as reported by Wang et al. (2013). Providing beneficial information for marker-assisted selection in breeding programs will improve pig production in Thai swine crossbreeds. Therefore, the objective of this research was to identify candidate gene markers based on their gene function related to meat quality traits in pigs.

\section{MATERIAL AND METHODS}

\section{Animals and sample collection}

A total of 313 commercial pigs were split into 5 groups based on five Duroc (DR) breed fractions, including $1=100 \% \mathrm{DR}(\mathrm{n}=227), 2=50 \% \mathrm{DR} \times 50 \%$ Large white $(\mathrm{LW})(\mathrm{n}=$ $7), 3=50 \% \mathrm{DR} \times 50 \%$ Landrace $(\mathrm{LR})(\mathrm{n}=41), 4=75 \% \mathrm{DR} \times 25 \% \mathrm{LW}(\mathrm{n}=18)$, and $5=$ $50 \%$ DR $\times 25 \% \mathrm{LW} \times 25 \% \mathrm{LR}(\mathrm{n}=20)$. The pigs were reared under evaporative cooling housing and under the same management conditions. A total of 313 pigs were randomly sampled for genomic DNA extraction and genotyping. The initial live body weights of sampled pigs ranged from $30-60 \mathrm{~kg}$, and they were reared in common pens to observe the growth performance. Pigs were fed ad libitum with the same rations as the testing station, and the individual feed intake and body weight were recorded using feed intake recording equipment. The pigs were slaughtered at around 190 days of age (140-238 days). The meat quality traits of pigs, such as marbling score, color $\left(\mathrm{L}^{*}\right), \%$ cooking loss and shear force, were recorded when the slaughter weight of $88-160 \mathrm{~kg}$ was reached. Marbling scores were detected by standard industry score typing and assessed using a scale from 1 to 6 . Our research specified the score typing as 1 to 3 for suitability in Thailand where the grouping scores 2-3 and 4-6 form the standard industry score typing. Only a general indication of lightness of meat color $\left(\mathrm{L}^{*}\right)$ was determined with a colorimeter. Cooking loss was the differential of sample weights before and after incubation at $75^{\circ} \mathrm{C}$ for $10 \mathrm{~min}$. WarnerBratzler probes were used to measure shear force.

\section{PCR-RFLP genotyping}

The primer characteristics of each candidate gene are shown in Table 1. The restriction fragments of each candidate gene were amplified in a total reaction volume of 10 $\mu \mathrm{L}$ containing: $1 \mu \mathrm{L}$ of genomic DNA, $1.5 \mu \mathrm{L}$ of $10 \mathrm{X}$ buffer with $\mathrm{MgCl}_{2}, 1 \mu \mathrm{L}$ of dNTPs, 1 $\mu \mathrm{L}$ of each primer and $0.25 \mathrm{U}$ of Taq Polymerase. The PCR protocol consisted of an initial denaturation at $95^{\circ} \mathrm{C}$ for $5 \mathrm{~min}$ followed by 35 cycles of $95^{\circ} \mathrm{C}$ for $45 \mathrm{~s}, 60-66^{\circ} \mathrm{C}$ for $30-45 \mathrm{~s}$ based on annealing temperature of each gene (Table 1), and $72^{\circ} \mathrm{C}$ for $60 \mathrm{~s}$, and a final elongation step at $72^{\circ} \mathrm{C}$ for $1.5 \mathrm{~min}$. Genomic DNA fragments were digested by restriction endonuclease enzymes (incubated overnight at $37^{\circ} \mathrm{C}$ ) and the digested fragments were separated by $2 \%$ agarose gel electrophoresis. All gene polymorphisms were identified by the Gel Documentary system. 
Table 1. Primers and restriction enzymes in each candidate gene for marbling score and meat quality traits in purebred and crossbred Duroc pigs.

\begin{tabular}{|c|c|c|c|c|c|}
\hline $\begin{array}{l}\text { Candidate } \\
\text { genes }\end{array}$ & $\begin{array}{l}\text { 5'-sequence-3' } \\
\text { Forward / Reverse primer }\end{array}$ & $\begin{array}{l}\text { AT. } \\
\left({ }^{\circ} \mathbf{C}\right)^{4}\end{array}$ & $\begin{array}{l}\text { Res. } \\
\text { Enz. }\end{array}$ & $\begin{array}{l}\text { PCR } \\
\text { Sizes (bp) }\end{array}$ & $\begin{array}{l}\text { Res. Enz. } \\
\text { production sizes (bp) }\end{array}$ \\
\hline$A D R B 3^{1}$ & $\begin{array}{l}\text { CGTTCAACCCGCTCATCTACTGCI } \\
\text { GTTCCCTACTCTGTGCCCGTCTT }\end{array}$ & 66 & TaqI & 315 & $\begin{array}{l}\mathrm{A}=315 \\
\mathrm{G}=143,172\end{array}$ \\
\hline$L I P E^{2}$ & $\begin{array}{l}\text { CGCACAATGACACAGTCACTGGT/ } \\
\text { AGGCAGCGGCCGTAGAAGCA }\end{array}$ & 66 & BsaHI & 497 & $\begin{array}{l}A=307,190 \\
G=240,190,67\end{array}$ \\
\hline$L E P R^{1}$ & $\begin{array}{l}\text { TGCCTGCTGGAATCTCAAAG/ } \\
\text { TTCCCTGCAATGTTGTCTGC }\end{array}$ & 66 & Tsp509I & 184 & $\begin{array}{l}\mathrm{A}=184 \\
\mathrm{G}=113,71\end{array}$ \\
\hline$C A S T^{3}$ & $\begin{array}{l}\text { AATGAGCAGCCAACATCAGA/ } \\
\text { TTCCCATAGCCCACAAGAAG }\end{array}$ & 60 & HinfI & 376 & $\begin{array}{l}A=376 \\
G=129,247\end{array}$ \\
\hline$C A P N 1^{3}$ & $\begin{array}{l}\text { CTGCTGCCCACCAAAGAC/ } \\
\text { CTCGTAGCTGCCATTCACC }\end{array}$ & 60 & HhaI & 197 & $\begin{array}{l}\mathrm{T}=132,65 \\
\mathrm{C}=91,65,41\end{array}$ \\
\hline
\end{tabular}

${ }^{\mathrm{T}}$ Wang et al. (2013), ${ }^{2}$ Xue et al. (2015), ${ }^{3}$ Gandolfi et al. (2011), ${ }^{4}$ Annealing temperatures, ${ }^{5} L I P E=$ Lipes E hormone, $L E P R=$ leptin receptor, $A D R B 3=$ adrenoceptor beta $3, C A P N I=$ Calpain, $C A S T=$ calpastatin gene, ${ }^{6}$ Restriction enzymes.

\section{Statistical analysis}

\section{Genetic parameter estimates}

Single trait via animal models was used for estimated variances and heritability, while genetic correlations were estimated by a bivariate threshold linear model between marbling score (threshold trait) and linear traits, as shown in equation 1 . The genetic parameters were estimated with Bayesian analysis via Gibbs sampling by using the THRGIBBS1F90 program and G0+93

We used the Gibbs1f90 program developed by Tsuruta and Misztal (2006). The details in posterior distribution, with a Gibbs chain of 300,000 cycles were analyzed. The first 50,000 were used for burn-in samples. The autocorrelation was less than 0.25 and saved only one sample from every 50 iterations. The best linear unbiased prediction (BLUP) was used for estimated breeding value (EBV) analysis.

$$
\left[\begin{array}{l}
\delta \\
y
\end{array}\right]=\left[\begin{array}{cc}
X_{1} & 0 \\
0 & X_{2}
\end{array}\right]\left[\begin{array}{l}
\beta_{1} \\
\beta_{2}
\end{array}\right]+\left[\begin{array}{cc}
Z_{1} & 0 \\
0 & Z_{2}
\end{array}\right]\left[\begin{array}{l}
\alpha_{1} \\
\alpha_{2}
\end{array}\right]+\left[\begin{array}{l}
\varepsilon_{1} \\
\varepsilon_{2}
\end{array}\right]
$$

Assumption of a and $\varepsilon$ is

$$
\operatorname{var}\left[\begin{array}{l}
\mathbf{a} \\
\boldsymbol{\varepsilon}
\end{array}\right]=\left[\begin{array}{cc}
\mathbf{G} \otimes \mathbf{A} & \mathbf{0} \\
\mathbf{0} & \mathbf{R} \otimes \mathbf{I}
\end{array}\right]
$$

Where $\delta$ and y is the vector of observations of threshold traits and continuous traits, $\beta$ is the vector of fixed effects, a is the vector of additive genetic effects, $\boldsymbol{\varepsilon}$ is vector of residuals, $A$ is the additive genetic relationship matrix between animals, $X_{i}$ and $Z_{i}$ are the incidence matrices for fixed and random effects of traits, respectively, and $\mathrm{i}, \mathrm{G}$ and $\mathrm{R}$ are the (co)variance matrices of vectors a and $\varepsilon$.

\section{Association analysis}

Genotype frequencies were estimated as per the formula of Falconer and Mackay (1996). A linear mixed model was used to analyze the association between each gene and traits i.e. marbling score $(\mathrm{MB})$, Color $\left(\mathrm{L}^{*}\right)$, \% cooking loss, and shear force. Breed groups, 
gender, genotype and covariate of slaughter weight were considered fixed effects, while sire was considered a random effect in the equation (2) and association with EBV was detected by equation (3).

$$
\begin{gathered}
y_{i j k}=\mu+\text { Sexi }_{i}+\text { Gene }_{j}+\beta 0(W t)+\text { Sire }_{k}+\varepsilon_{i j k} \\
E B V_{i j}=\mu+\text { Gene }_{j}+\varepsilon_{i j}
\end{gathered}
$$

Where, $y_{i j k}$ and $E B V_{i j}$ are the phenotypic and estimated breeding value of traits, $\mu$ is the overall mean, Sex $i$ is the effect of sex $i$, Gene $_{j}$ is the effect of genotype of gene $j$, $\beta 0(W t)$ is the regression of the slaughter weight (Wt) of test, Sire $k$ is the random effect of sire $k$ and $\varepsilon_{j}$ is the residual error.

\section{RESULTS AND DISCUSSION}

The marbling scores are shown in Figure 1. The frequencies of each score in this population were $28,30,23,11,4$ and $4 \%$ for scores 1 to 6 , respectively.

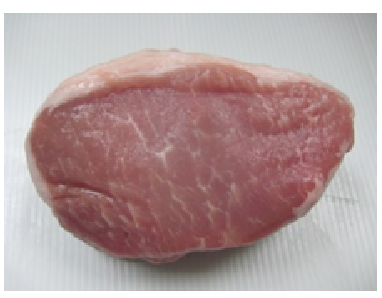

Score 1

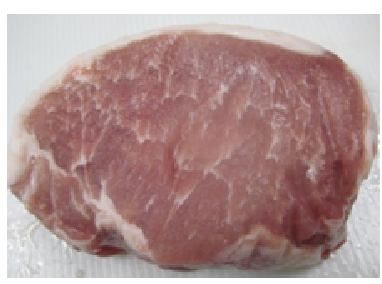

Score 4

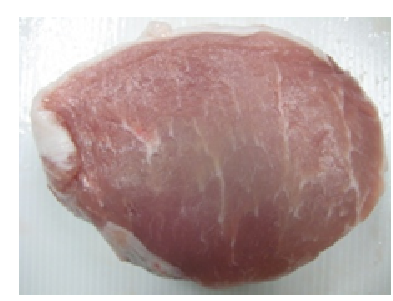

Score 2

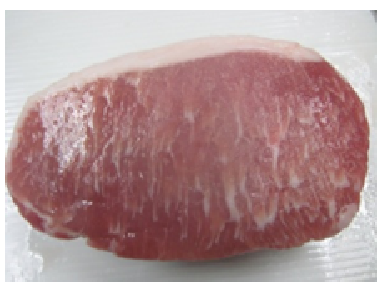

Score 5

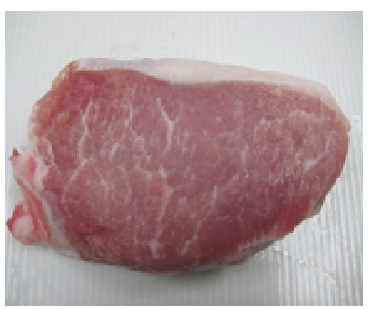

Score 3

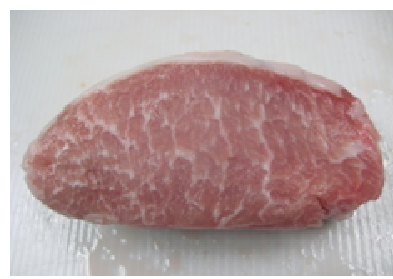

Score 6

Figure 1 Marbling score from 1 to 6 in Thai crossbred pigs

\section{The effect of breed groups on marbling and meat quality traits}

The breed group has an effect on traits, especially marbling traits, percent cooking loss, and shear force (Table 2). In Duroc purebreds, it appears that the marbling score were higher than in Duroc crossbreds $(\mathrm{P}<0.01)$. Meanwhile, all parameters were significantly higher in 50\% DR x 50\% Large white (LW) compared with the others. This result is similar to what was found by Ellis et al. (1996), who reported that the Duroc purebred has good 
meat quality and is highly marbled. Moreover, the Duroc crossbred (Shanzhu $\times$ Duroc) has good meat and fatness traits, as determined by the IMF content and fatty acid composition.

Table 2. The mean \pm SE to test effect of breed groups on marbling scores and meat quality traits of marbling score and meat quality traits in purebred and crossbred Duroc pigs.

\begin{tabular}{|c|c|c|c|c|c|c|}
\hline \multirow[t]{2}{*}{ Traits $^{2}$} & \multicolumn{5}{|c|}{ Breed groups $^{1}$} & \multirow[t]{2}{*}{ P-value } \\
\hline & $100 \% \mathrm{DR}$ & $50 \%$ DR x $50 \%$ LW & $50 \%$ DR x 50\%LR & $75 \%$ DR x $25 \% \mathrm{LW}$ & $50 \%$ DR x $25 \%$ LW x $25 \%$ LR & \\
\hline MB6 & $2.63 \pm 0.27^{b}$ & $1.88 \pm 0.29^{a c}$ & $2.11 \pm 0.46^{\mathrm{abc}}$ & $2.02 \pm 0.19^{c}$ & $1.15 \pm 0.07^{\mathrm{a}}$ & $<.0001$ \\
\hline MB3 & $2.01 \pm 0.04^{\mathrm{b}}$ & $1.61 \pm 0.15^{\mathrm{c}}$ & $1.85 \pm 0.24^{\mathrm{bc}}$ & $1.70 \pm 0.10^{\mathrm{c}}$ & $1.15 \pm 0.14^{\mathrm{a}}$ & $<.0001$ \\
\hline Color $\left(\mathrm{L}^{*}\right)$ & $44.76 \pm 0.09$ & $45.38 \pm 0.33$ & $44.98 \pm 0.52$ & $44.68 \pm 0.21$ & $44.88 \pm 0.31$ & 0.450 \\
\hline Cookingloss $(\%)$ & $28.39 \pm 0.10^{\mathrm{b}}$ & $29.62 \pm 0.33^{\mathrm{c}}$ & $28.10 \pm 0.53^{\mathrm{b}}$ & $28.62 \pm 0.22^{\mathrm{b}}$ & $28.77 \pm 0.32^{\mathrm{abc}}$ & 0.008 \\
\hline Shear fore $(\mathrm{kg})$ & $4.41 \pm 0.01^{\mathrm{a}}$ & $4.45 \pm 0.02^{\mathrm{ab}}$ & $4.46 \pm 0.03^{\mathrm{ab}}$ & $4.45 \pm 0.01^{\mathrm{b}}$ & $4.40 \pm 0.02^{\mathrm{ab}}$ & 0.012 \\
\hline
\end{tabular}

\section{Genetic parameters}

Heritability, genetic parameters and phenotypic parameters for the traits are presented in Table 3. The estimates of heritability for marbling score and meat quality were moderate $(0.19-0.38)$, except for color $\left(\mathrm{L}^{*}\right)$, which has a high estimated heritability. These results confirm those of several previous studies, which reported the heritability of meat quality traits to range from 0.19-0.46 for color (Sonesson et al., 1998, Tholen et al., 2005) and highly heritable (0.45) for pork tenderness in both Duroc and Landrace pigs (Lo et al., 1992, Suzuki et al., 2005).

Table 3. Heritability (diagonal), genetic correlation (above diagonal) and phenotypic correlation (below diagonal) of marbling score and meat quality traits in purebred and crossbred Duroc pigs.

\begin{tabular}{lccccc}
\hline Traits & MB3 & MB6 & Color $\left(\mathbf{L}^{*}\right)$ & Cookingloss $(\%)$ & Shear Force \\
\hline MB3 & 0.21 & 0.93 & 0.20 & 0.29 & -0.43 \\
MB6 & 0.94 & 0.19 & 0.05 & 0.29 & -0.17 \\
Color (L*) & 0.01 & -0.02 & 0.64 & 0.48 & -0.52 \\
Cooking loss (\%) & -0.29 & -0.33 & 0.26 & 0.38 & -0.24 \\
Shear Force (kg) & -0.74 & -0.57 & -0.06 & 0.08 & 0.22 \\
\hline 'score typing of marbling; MB3 is 3 score and MB6 is 6 score. &
\end{tabular}

The phenotypic correlation was positive for marbling score (0.94) and negative for $\%$ cooking loss (MB3 vs \% cooking loss $=-0.29$, MB6 vs \% cooking loss $=-0.33$ ) and shear force $(\mathrm{MB} 3$ vs shear force $=-0.74$, MB6 vs shear force $=-0.57$ ). Genotypic correlation was positive with marbling score (0.93); thus a selection plan can be based on one trait for selection. Meanwhile, genetic correlation between marbling score and shear force was negative (MB3 vs shear force $=-0.43$, MB6 vs shear force $=-0.17$ ). As a result, improving marbling can lead to a decrease in shear force (more tenderness), which is consistent with previous reports (Ellis et al., 1996; Chen et al., 2014). For genotypic correlation between marbling score and \% cooking loss was positive (0.29) in this study, which could be for several reasons, such as gene expression specific to the population, the pleiotropic effects of genes on multiple traits, or linkage disequilibrium among distinct loci (Falconer and 
Mackay, 1996), which is in agreement with the results reported by Huff-Lonergan (2002). In addition, the genetic correlations between marbling score traits with color $\left(\mathrm{L}^{*}\right)$ were moderately positive. The color $\left(\mathrm{L}^{*}\right)$ was moderately correlated with \% cooking loss, so the propensity to increase color $\left(\mathrm{L}^{*}\right)$ increases $\%$ cooking loss. The phenotype correlations between marbling score and color $\left(\mathrm{L}^{*}\right)$ and between tenderness and color $\left(\mathrm{L}^{*}\right)$ and cooking loss were quite low. Consequently, phenotypes with these traits were avoided.

\section{PCR-RFLP genotyping and Genotype frequencies}

Genotyping and gene frequencies are shown in Figure 2 and Table 4. All of the genes showed variation. However, genotype frequency, AA of the CAST gene and CC of CAPN1 gene were detected at only 2 and $12 \%$, respectively in this population, which is in contrast with the report of Gandolfi et al. (2011), who detected 10\% AA genotype and zero for CC genotype in Italian Durocx(LandracexLarge White) crossbred pigs.

\section{Gene association}

The association studies between candidate genes and meat quality traits are shown in Table 4 for both phenotype and genotype (EBV). The ADRB3 variant c.1192G>A was found to be significantly associated with marbling score in both. An association between $A D R B 3$ gene polymorphism and porcine fatness traits was previously reported by Wang et al. (2013). It is noteworthy that the heterozygous genotype (AG) of the ADRB3 gene has a higher marbling effect than the homozygous genotype (GG). It seems to be that the increased marbling of the AG genotype may be an over-dominance effect, which is consistent with a previous report (Wang et al., 2013).

In our study (Table 4), the LIPE c.442G>A SNP was not significantly associated with marbling score and meat quality traits in both phenotype and genotype (EBV). Indeed, the LIPE gene has an effect on accumulating fat in muscle and backfat content because it is involved with anti-lipolysis (Gerbens et al., 2000; Xue et al., 2015). Meanwhile, LEPR was not significantly associated for all meat quality traits as well. This result is in contrast with that of Lee et al. (2012), who reported that the LEPR gene has been used for a candidate gene to improve fatness traits. The $L E P R$ gene has been associated with backfat thickness and intramuscular fat content (IMF) in Korean crossbred animals (Lee et al., 2012). The cause of non-significant SNPs in association studies may be due to different breeds, as Ovilo et al. (2005) found that the SNP at the same position in the LEPR gene was not significantly associated with IMF in an Iberian crossbred.

Calpain1 (CAPN1) g.157T>C was genotyped and used as a candidate gene because some studies have reported that calpain3 was not detected in pig meat (Parr et al., 1999; Gandolfi et al., 2011). In our study, CAPNI was significantly associated with the EBV of cooking loss percentage. The CC genotype showed a low cooking loss percentage. Indeed, CAPN1 encodes the large subunit ( $\mu$-calpain) of an enzyme that has significant roles in proteolysis processes in pork (Huff-Lonergan and Lonergan, 2005; Kemp et al., 2010). High calpain activity leads to enhanced tenderness because it affects cleavage of specific myofibrillar proteins (Gandolfi et al., 2011). James and Yang (2011) reported that the water holding capacity of meat showed a strong linear correlation with tenderness. However, CAPN1 was not significantly associated with shear force or tenderness/toughness in our 
study. In contrast, porcine calpastatin (CAST) is an antagonist of calpain, which means that high activity leads to decreased proteolysis and enhanced meat toughness (Kent et al., 2004; Kemp et al., 2010). We found that the CAST gene was significantly associated with phenotypic and EBV shear force, with the GG genotype showing a lower shear force compared to the AG genotype. Moreover, CAST was associated with affected meat color, $\mathrm{pH}$, water holding-capacity and texture parameters as well (Ropka-Molik et al., 2014).

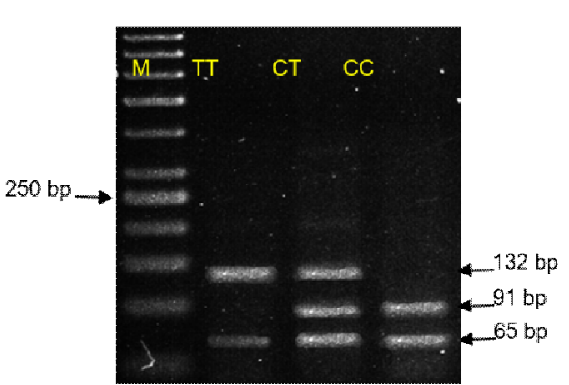

a) CAPN1

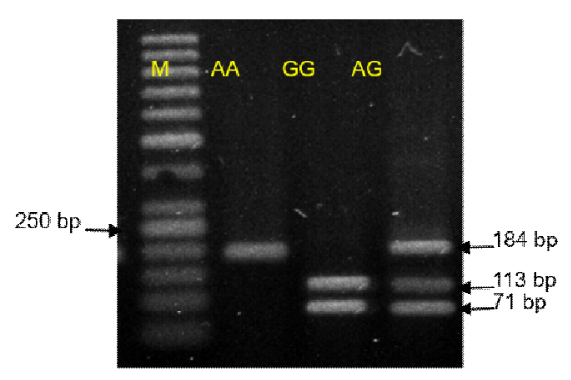

c) LEPR

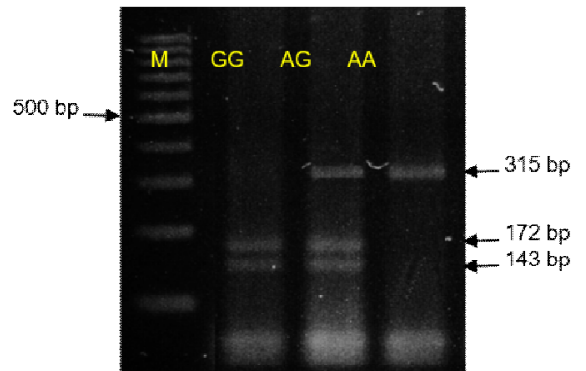

b) $A D R B 3$

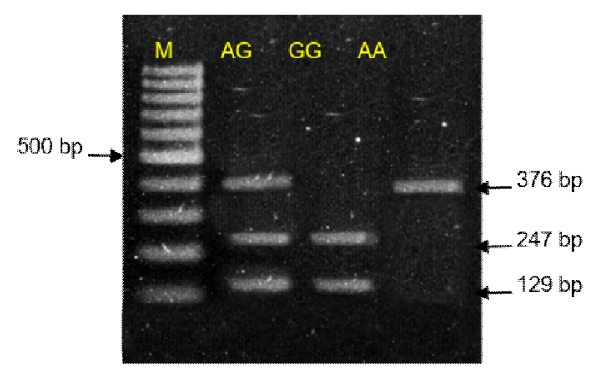

d) CAST

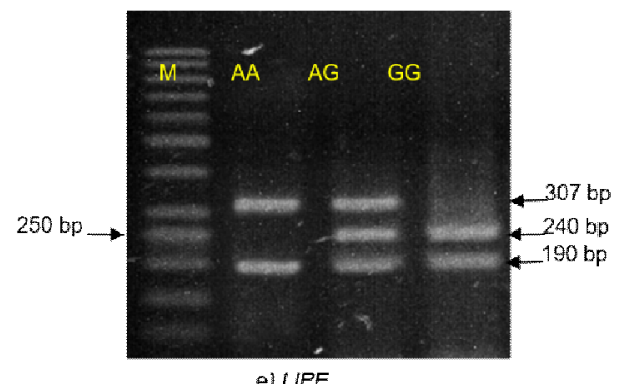

e) LIPE

Figure 2. Genetic polymorphisms of PCR products of candidate genes (CAPN1, ADRB3, LEPR, CAST, and $L I P E)$ after amplifying with allele-specific primers and cutting with restriction enzymes: a) Calpain/HhaI: allele $\mathrm{T}$ (132, 65 bp) and allele C (91, 65, 41 bp); b) Adrenoceptor beta 3/TaqI: allele A (315 bp) and allele G (172, 143 bp); c) Leptin receptor/Tsp509I: allele A (184 bp) and allele G (113, $71 \mathrm{bp})$; d) Calpastatin gene/HinfI, allele A (376 bp) and allele G (129, 247 bp); and e) Lipes E hormone/BsaHI, allele A (307, 190 bp) allele G (240, 190, 67 bp) in pigs. 
Table 4. Genotype frequency (in brackets) and candidate gene association analysis with phenotypic and estimated breeding value (EBV) of marbling score and meat quality traits in purebred and crossbred Duroc pigs.

\begin{tabular}{|c|c|c|c|c|c|c|c|c|c|c|c|}
\hline \multirow[t]{3}{*}{ Candidate genes $^{1}$} & \multirow{3}{*}{$\begin{array}{l}\text { Genotype } \\
\text { Frequency }\end{array}$} & \multicolumn{5}{|c|}{ Phenotypic } & \multicolumn{5}{|l|}{ EBV } \\
\hline & & MB3 & MB6 & & Cooking & & MB3 & MB6 & Color & & \\
\hline & & $\left(\right.$ score $\left.^{2}\right)$ & $\left(\right.$ score $\left.^{2}\right)$ & $\begin{array}{l}\text { Color } \\
\left(\mathbf{L}^{*}\right)\end{array}$ & $\begin{array}{l}\text { loss } \\
(\%)\end{array}$ & Shear Force & (score) & (score) & $\left(\mathbf{L}^{*}\right)$ & $\begin{array}{l}\text { Cooking } \\
\text { loss }(\%)\end{array}$ & Shear Force \\
\hline LIPE & $\mathrm{AA}(0.11)$ & 2.12 & 2.72 & 45.25 & 29.23 & 4.32 & 0.40 & 0.52 & 5.22 & 3.55 & -0.003 \\
\hline \multirow[t]{3}{*}{$\mathrm{n}=300$} & AG (0.46) & 2.11 & 2.79 & 44.67 & 28.59 & 4.69 & 0.37 & 0.53 & 5.25 & 3.61 & 0.03 \\
\hline & GG (0.43) & 2.14 & 2.70 & 44.61 & 28.74 & 4.39 & 0.39 & 0.47 & 5.25 & 3.46 & 0.00 \\
\hline & $\mathrm{P}$-value & 0.94 & 0.87 & 0.14 & 0.15 & 0.37 & 0.92 & 0.94 & 0.99 & 0.87 & 0.28 \\
\hline$L E P R$ & AA (0.19) & 2.02 & 2.54 & 44.68 & 28.80 & 4.45 & 0.31 & 0.34 & 4.84 & 3.22 & 0.004 \\
\hline \multirow[t]{3}{*}{$\mathrm{n}=313$} & AG (0.48) & 2.12 & 2.75 & 44.97 & 29.01 & 4.54 & 0.37 & 0.50 & 5.42 & 3.61 & 0.024 \\
\hline & GG (0.33) & 2.23 & 2.94 & 44.88 & 28.75 & 4.40 & 0.48 & 0.67 & 5.47 & 3.46 & -0.004 \\
\hline & P-value & 0.14 & 0.17 & 0.57 & 0.49 & 0.86 & 0.30 & 0.31 & 0.46 & 0.57 & 0.36 \\
\hline$A D R B 3$ & $\mathrm{AA}(0.20)$ & $2.16 \mathrm{ab}$ & $2.80 \mathrm{ab}$ & 44.91 & 29.05 & 4.37 & $0.39 \mathrm{ab}$ & $0.53 \mathrm{ab}$ & 5.35 & 3.66 & -0.015 \\
\hline \multirow[t]{3}{*}{$\mathrm{n}=305$} & AG (0.38) & $2.22 \mathrm{~b}$ & $2.92 \mathrm{~b}$ & 44.70 & 28.68 & 4.34 & $0.48 b$ & $0.66 \mathrm{~b}$ & 5.29 & 3.38 & 0.015 \\
\hline & GG (0.42) & $1.99 \mathrm{a}$ & $2.49 \mathrm{a}$ & 44.92 & 28.83 & 4.69 & $0.28 \mathrm{a}$ & $0.32 \mathrm{a}$ & 5.08 & 3.25 & 0.025 \\
\hline & $\mathrm{P}$-value & 0.01 & 0.03 & 0.55 & 0.42 & 0.37 & 0.05 & 0.04 & 0.83 & 0.58 & 0.28 \\
\hline CAPNI & $\mathrm{CC}(0.12)$ & 2.16 & 2.80 & 45.07 & 29.16 & 4.38 & 0.43 & 0.56 & $3.88 \mathrm{a}$ & $2.64 a$ & -0.01 \\
\hline \multirow[t]{3}{*}{$\mathrm{n}=313$} & CT (0.35) & 2.12 & 2.74 & 44.68 & 28.76 & 4.39 & 0.37 & 0.50 & $5.86 \mathrm{~b}$ & $3.83 \mathrm{~b}$ & 0.03 \\
\hline & TT (0.53) & 2.10 & 2.67 & 44.77 & 28.64 & 4.62 & 0.36 & 0.45 & $5.97 \mathrm{~b}$ & $3.81 \mathrm{~b}$ & 0.00 \\
\hline & $\mathrm{P}$-value & 0.85 & 0.83 & 0.60 & 0.38 & 0.60 & 0.87 & 0.88 & $<0.01$ & 0.03 & 0.19 \\
\hline & AA (0.02) & Non & Non & Non & Non & Non & Non & Non & Non & Non & Non \\
\hline \multirow[t]{3}{*}{$\mathrm{n}=313$} & $\mathrm{AG}(0.16)$ & 2.11 & 2.66 & 44.66 & $28.53 \mathrm{a}$ & $4.85 \mathrm{a}$ & 0.35 & 0.41 & 4.98 & 3.09 & $0.05 \mathrm{a}$ \\
\hline & GG (0.82) & 2.15 & 2.81 & 45.03 & $29.17 \mathrm{~b}$ & $4.08 \mathrm{~b}$ & 0.42 & 0.60 & 5.51 & 3.78 & $-0.03 b$ \\
\hline & P-value & 0.68 & 0.48 & 0.16 & 0.02 & 0.02 & 0.49 & 0.38 & 0.32 & 0.07 & $<0.01$ \\
\hline
\end{tabular}

1 LIPE=Lipes E hormone, LEPR=leptin receptor, ADRB3=adrenoceptor beta 3, CAPN1=Calpain, CAST=calpastatin gene. $2 \mathrm{Score} 1=$ marbling score 1 ; Score $2=$ marbling score $2+3$; Score $3=$ marbling score $4+5+6$ Non $=$ Non-analysis

\section{CONCLUSIONS}

The heterozygous (AG) genotype of ADRB3 was significantly associated with marbling score. The CAPN and CAST genes were significantly associated with cooking loss and shear force, respectively. In breeding applications, the AG genotype of ADRB3 could be used as a marker for assisted selection to improve marbling scores. Also, the GG genotype of CAST is the most appropriate gene for selection of the pork tenderness trait.

\section{ACKNOWLEDGMENTS}

We would like to thank the KKU-Post-Doctoral project for providing funding for this research. We would also like to extend our gratefulness to the Betagro Hybrid International Company Limited, Thailand, for help with data collection and management. We are grateful to the Animal Genomic Laboratory for providing laboratory facilities and support.

\section{CONFLICTS OF INTEREST}

The authors declare no conflict of interest.

\section{REFERENCES}

Chen JN, Jiang YZ, Cen WM, Xing SH, et al. (2014). Distribution of $H-F A B P$ and ACSL4 gene polymorphisms and their associations with intramuscular fat content and backfat thickness in different pig populations. Genet. Mol. Res. 13: 6759-6772.

Cho ES, Lee KT, Choi JW, Jeon HJ, et al. (2015). Novel SNPs in the growth arrest and DNA damage-inducible protein 45 alpha gene (GADD45A) associated with meat quality traits in Berkshire pigs. Genet. Mol. Res. 14: 8581-8588. 
de Koning DJ, Janss LL, Rattink AP, van Oers PA, et al. (1999). Detection of quantitative trait loci for backfat thickness and intramuscular fat content in pigs (Sus scrofa). Genetics. 152: 1679-1690.

Ellis M, Webb AJ, Avery PJ and Brown I (1996). The influence of terminal sire genotype, sex, slaughter weight, feeding regimen and slaughter house on growth performance, and carcass and meat quality in pigs and on the organoleptic properties of fresh pork. J. Animal Sci. 74: 521-530.

Falconer D and Mackay T (1996). Introduction to Quantitative Genetics. 4th Edition. Longman Editors, Essex, UK.

Fortin A, Robertson WM and Tong AKW (2005). The eating quality of Canadian pork and its relationship with intramuscular fat. Meat Sci. 69: 297-305.

Gandolfi G, Pomponio L, Ertbjerg P, Karlsson AH, et al. (2011). Investigation on CAST, CAPN1 and CAPN3 porcine gene polymorphisms and expression in relation to post-mortem calpain activity in muscle and meat quality. Meat Sci. 88: 694-700.

Gerbens F, Van Erp AJM, Harders FL, Verburg FJ, et al. (1999). Effect of genetic variants of the heart fatty acidbinding protein gene on intramuscular fat and performance traits in pigs. J. Anim. Sci. 77: 846-852.

Gerbens F, de Koning DJ, Harders FL, Meuwissen TH, et al. (2000). The effect of adipocyte and heart fatty acid-binding protein genes on intramuscular fat and backfat content in Meishan crossbred pigs. J. Anim Sci. 78: 552-559.

Huff-Lonergan E (2002). Correlations among selected pork quality traits. J. Animal Sci. 80: 617-627.

Huff-Lonergan E and Lonergan SM (2005). Mechanisms of water-holding capacity of meat: The role of postmortem biochemical and structural changes. Meat Sci. 71: 194-204.

James B and Yang SW (2011). Testing meat tenderness using an in situ straining stage with variable pressure scanning electron microscopy. Procedia Food Sci. 1: 258-266.

Kemp CM, Sensky PL, Bardsley RG, Buttery PJ, et al. (2010). Tenderness-An enzymatic view. Meat Sci. 84: 248-256.

Kent MP, Spencer MJ and Koohmaraie M (2004). Postmortem proteolysis is reduced in transgenic mice overexpressing calpastatin. J. Animal Sci. 82: 794-801.

Lee KT, Byun MJ, Kang KS, Hwang H, et al. (2012). Single nucleotide polymorphism association study for backfat and intramuscular fat content in the region between SW2098 and SW1881 on pig chromosome 6. J. Animal Sci. 90: 1081-1087.

Lo LL, McLaren DG, McKeith FK, Fernando FL, et al. (1992). Genetic analysis of growth, real time ultrasound, carcass and pork quality traits in Duroc and Landrace pigs: II. Heritabilities and correlations. J. Animal Sci. 70: 2357-2396.

Mellink CH, Lahbib-Mansais Y, Yerle M and Gellin J (1993). Localization of four new markers to pig chromosomes 1, 6, and 14 by radioactive in situ hybridization. Cytogenet. Cell Genet. 64: 256-260.

Miyoshi H, Perfield Jr. JW, Obin MS and Greenberg AS (2008). Adipose triglyceride lipase regulates basal lipolysis and lipid droplet size in adipocytes. J. Cell. Biochem. 105: 1430-1436.

Nowacka-Woszuk J, Szczerbal I, Fijak-Nowak H and Switonski M (2008). Chromosomal localization of 13 candidate genes for human obesity in the pig genome. J. Appl. Genet. 49: 373-377.

Ovilo C, Fernandez A, Noguera JL, Barragan C, et al. (2005). Fine mapping of porcine chromosome 6 QTL and LEPR effects on body composition in multiple generations of an Iberian by Landrace intercross. Genet. Res. 85: 57-67.

Parr T, Sensky PL, Scothern GP, Bardsley RG, et al. (1999). Relationship between skeletal muscle-specific calpain and variable postmortem tenderization in porcine longissimus muscle. J. Anim. Sci. 77: 661-668.

Reardon W, Mullen AM, Sweeney T and Hamill RM (2010). Association of polymorphisms in candidate genes with colour, water-holding capacity, and composition traits in bovine M. longissimus and M. semimembranosus. Meat Sci. 86: 270-275.

Ropka-Molik K, Bereta A, Tyra M, Różycki M, et al. (2014). Association of calpastatin gene polymorphisms and meat quality traits in pig. Meat Sci. 97: 143-150.

Sonesson AK, de Greef KH and Meuwissen THE (1998). Genetic parameters and trends of meat quality, carcass composition and performance traits in two selected lines of large white pigs. Livestock Prod. Sci. 57: 23-32.

Suzuki K, Irie M, Kadowaki H, Shibata T, et al. (2005). Genetic parameter estimates of meat quality traits in Duroc pigs selected for average daily gain, longissimus muscle area, backfat thickness, and intramuscular fat content. J. Anim. Sci. 83: 2058-2065.

Tholen E, Jüngst H, Schulze-Langenhorst C and Schellander K (2005). Genetic foundation of meat quality traits of station tested slaughter pigs in North Rhine-Westphalia (Germany). A status report. Archiv. Tierzucht. 48: 123-130.

Tsuruta S and Misztal I (2006). THRGIBBS IF90 for estimation of variance components with threshold and linear models. J. Dairy Sci. 89 (Suppl. 1): 15.

Wang W, Xue W, Zhou X, Zhang L, et al. (2013). Effects of candidate genes' polymorphisms on meat quality traits in pigs. Acta Agricult. Scand. Sect. A Anim. Sci. 62:120-126.

Xue W, Wang W, Jin B, Zhang X, et al. (2015). Association of the ADRB3, FABP3, LIPE, and LPL gene polymorphisms with pig intramuscular fat content and fatty acid composition. Czech J. Animal Sci. 60: 60-66.

Zechner R, Kienesberger PC, Haemmerle G, Zimmermann R, et al. (2009). Adipose triglyceride lipase and the lipolytic catabolism of cellular fat stores. J. Lipid Res. 50: 3-21.

Zhang S, Knight TJ, Stalder KJ, Goodwin RN, et al. (2009). Effects of breed, sex and halothane genotype on fatty acid composition of triacylglycerols and phospholipids in pork longissimus muscle. J. Animal Breed. Genet. 126: 259268.

Genetics and Molecular Research 19 (2): gmr18615

CFUNPEC-RP www.funpecrp.com.br 